\title{
INVESTIGATION OF AMINE BASED CARBON-DIOXIDE AND HYDROGEN-SULPHIDE SEPARATION TECHNOLOGIES FOR BIOGASES
}

\author{
Zsuzsanna Szolyák \\ PhD student, University of Miskolc \\ Petroleum and Natural Gas Institute, Natural Gas Engineering Department \\ 3515 Miskolc, Miskolc-Egyetemváros, e-mail: szolyak.zsuzsanna@gmail.com \\ István Szunyog \\ associate professor, University of Miskolc \\ Petroleum and Natural Gas Institute, Natural Gas Engineering Department \\ 3515 Miskolc, Miskolc-Egyetemváros, e-mail: szunyog.istvan@uni-miskolc.hu
}

\begin{abstract}
Biogas has been used since the beginning of the 19th century, which is a gaseous material formed during the anaerobic fermentation of organic substance. It is extremely versatile in its use, it is mostly used to produce heat and electricity, but it can also be used as a motor fuel. To produce these gases we can use organic materials and wastes from agriculture, food industry and communal sector. When the produced biogas is utilized, less $\mathrm{CO}_{2}$ is released into the environment than with other primary energy sources, it has zero emissions for the whole "carbon cycle" and can therefore be considered positive. The calorific value of biogas is much lower than in the case of natural gas, however, we can increase the energy content by compression and decarbonisation, which can even produce a biomethane which can be equivalent to natural gas. Depending on the feedstock, the methane content of the biogas can change over a very wide range, and the gas mixture can also contain other gases and water vapor. Thus, in order to improve these parameters, undesirable components must be removed from the gas. Several methods can be used to remove unwanted components of the biogas, however, this study focuses exclusively on amino purification technology. [1.]
\end{abstract}

Keywords: biogas, biomethane, cleaning technologies, amino-purification technology, modelling

\section{The relationship between energy demand and environmental pollution}

The scientific and technical advances of the recent decades have provided mankind some tools and technological solutions that have had an exponential impact on our environment. Based on the experience so far, it can be said that the growing consumer demands will definitely harm the environment. According to the latest estimates, transport accounts for a quarter of the world's energy needs, thus making a major contribution to greenhouse gas emissions. Most of it comes from burning fossil fuels, which is why it is important for governments to support users in favouring one of the most environmentally friendly modes of transport. One of the main causes of air pollution is the amount of gases emitted by petrol and diesel engines. Air pollution from road traffic is determined by the number, modernity, technical condition of the vehicles and the type of the fuel. [2.]

We have carried out a detailed statistical analysis of the trends in energy consumption in Europe, and the following findings can be made: 
- Energy consumption has been on a fundamentally declining trend since the mid-2000s, but has started to increase again since 2014. However, the data from 2017 do not approach the intensity of energy consumption during the peak period. The biggest break was observed between 2008 and 2009, and obviously the global economic crisis which erupted in 2008 also played a big role in this.

- Considering the data, it can be said that the world's energy demand will continue to grow. Statistics show that an individual's energy consumption is lower than in previous years, however, the Earth's population continues to show an increasing trend.

- Although the role of renewable energy sources is becoming more and more important, it still does not play as important a role as fossil fuels.

Statistics show that the transport sector accounts for a significant share of energy demand. Regarding to the trends in the use of different propellants, further studies have been carried out, as a result of which the following conclusions can be made:

- In the case of the examined countries, it can be said that the largest share of motor fuels were diesel and petrol, which in several cases means more than $90 \%$.

- However, it has also emerged that there has been support in some European countries for the integration of other alternative energy sources into the system. [3.]

\section{Biogas as a possible alternative}

Biogas is a gaseous substance formed during the anaerobic fermentation of organic materials, which is combustible in a significant volume. However, it should be clarified that the calorific value of biogas is much lower than that of natural gas. Ergo, unwanted components must be removed from the biogas, thereby increasing its methane content and its energy content. Several methods are used to purify biogas: [4.]

- Water scrubbing (Physical absorption): Nowadays, this is one of the most common cleaning procedures. The technology focuses on the solubility of methane and carbon dioxide in water. The pressure of the raw biogas is increased and then it becomes necessary to reduce the resulting temperature increase. This is followed by another pressure increase followed by a repeated cooling phase. Biogas is fed at the bottom of the scrubber tower, while opposite it, water enters the system at the top of the tower. Water dissolves unwanted components from the gas, so that in the end a product gas containing up to $99 \%$ methane can be obtained.

- Organic-physical absorption ("glycol wash"): Similar to water scrubbing, only in this case an organic solvent (for example polyethylene glycol) is used instead of water. In this case, both carbon dioxide and hydrogen sulphide are more soluble.

- Amine washing (Chemical absorption): The required amine solution is fed at the top of the tower, while biogas is fed at the bottom of the tower. When counter-current materials meet, a chemical reaction occurs, eventually the purified gas leaves the top of the tower and the contaminated liquid at the bottom of the tower.

- Pressure Swing Adsorption (PSA): Activated carbons and molecular sieves at high pressure are used to sequester carbon dioxide. Regeneration of adsorbents is accomplished by pressure reduction, in which case the waste gas leaves the adsorber.

- Membrane separation technology: The essence of the technology is that the membranes used in the process allow carbon dioxide, water and ammonia to pass through, but methane only in a 
very small extent. Hydrogen sulphide, nitrogen, and oxygen are also able to flow through membranes but only in a limited extent. The separation of the gas components is determined by the partial pressure difference between the two sides of the membrane.

- Cryogenic process: The essence of the process is that the undesired carbon dioxide or other component is brought to a liquid state by cooling to its boiling point under high pressure, thus making it easily separable. [6.]

\section{Simulation model of amino purification technology}

Of the purification procedures listed, the study focuses exclusively on amino technology. We chose this procedure because we were able to make sure that the modelling software contained all the necessary components or modules that replaced the function of the given component, which are needed to map the real technology. Amines are actually carbon compounds containing nitrogen derived from ammonia, in which one or more hydrogen atoms in their molecules are replaced by a hydrocarbon group.

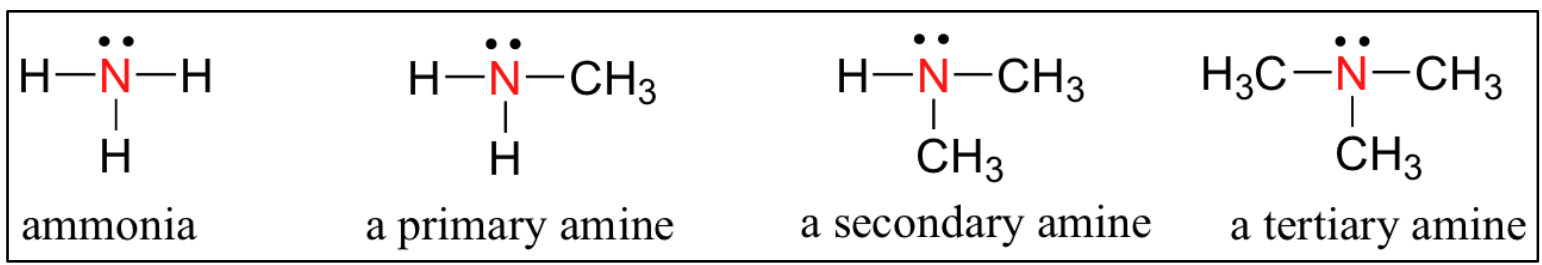

Figure 1. Amine groups (Source: https://chem.libretexts.org/).

Amines can be grouped as follows: [7.]

\section{Primary amines:}

- MEA: Monoethanol-amine

- DGA: Diglycol-amine

Secondary amines:

- DEA: Diethanol-amine

- DIPA: Diisopropanol-amine

Tertiary amines:

- TEA: Triethanol-amine

- MDEA: Methyl-diethanol-amine

Of the three groups, primary amines are considered to be the most reactive. Figure 2 shows the process of the cleaning technology. In fact, we can talk about two towers in this case. In the first tower, the raw biogas is purified, so $\mathrm{CO}_{2}$ and $\mathrm{H}_{2} \mathrm{~S}$ are separated from it. Raw biogas is fed in at the bottom of the tower and the necessary amine tincture at the top of the tower. The scrubbing liquid reacts with the fed biogas and absorbs the harmful components, then leaves at the bottom of the tower. Contaminated cleaning fluid must be regenerated in order to be used continuously, this regeneration takes place in another so-called regeneration tower. The two units are connected by a heat exchanger, through which the already regenerated amine can be returned to the absorber, thus closing the circuit. It should be noted that this is a simplified figure for understanding the technology, however, in reality, there are no two amino washing procedures that can be the same. 


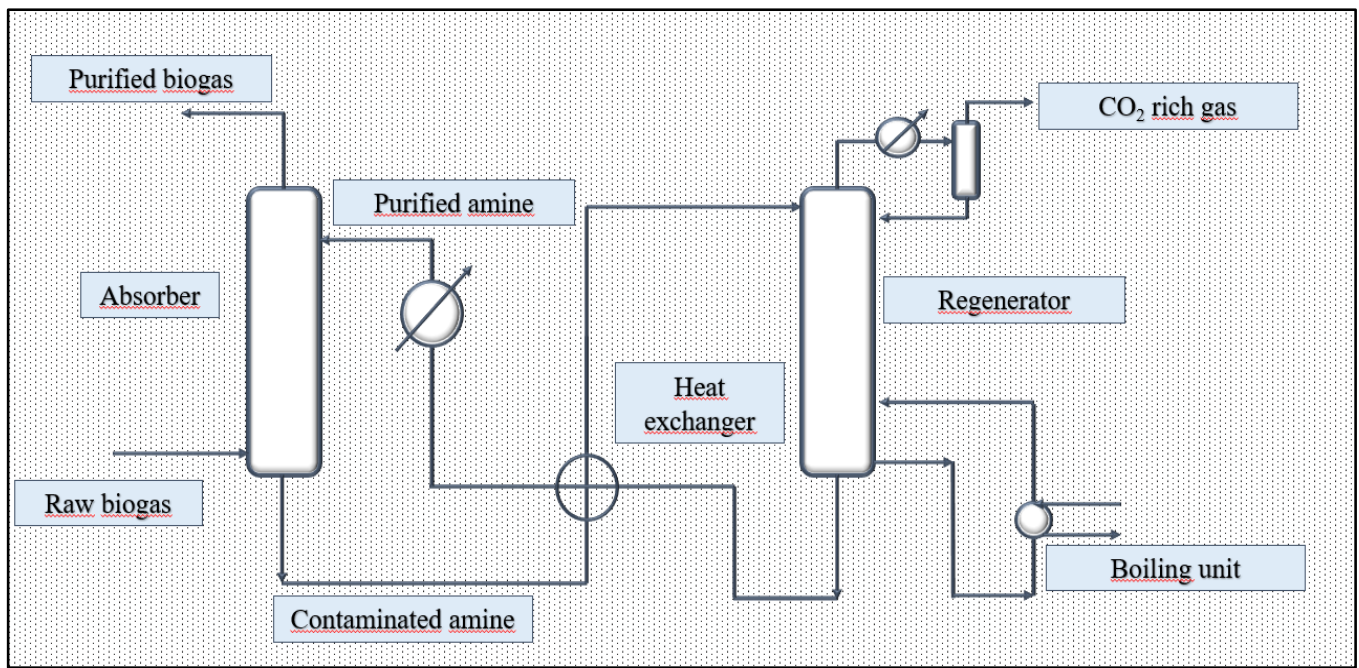

Figure 2. Amine washing technology (Source: own edit).

The model demonstrating the technology was created using Aspen Hysys simulation software. Before starting a particular design task, we can specify the required input parameters, for example the chemical compositions, physical characteristics, or even environmental effects desired for modelling, resulting in relatively accurate output calculation results. [8.] In the present case, we had to determine the composition, the temperature, the pressure, and the mass flow of the fed biogas, and we had to choose the type of amine tincture required for the purification process. As no real data from the industry were currently available, the necessary parameters were determined based on the processed literature. Since the composition of biogas depends on what the raw material of the processed waste is, it was actually possible to work on a given interval. During the calculations, three types of compositions were fed in, with no change in the values of the other parameters. In the present case, the amines added were Methyl Diethanol-amine, (MDEA) and Monoethanol-amine (MEA).

Table 1. Biogas compositions (Source: https://regi.tankonyvtar.hu/hu/tartalom/tamop425/ 0032_kornyezettechnologia/ch07s03.html, own edit)

\begin{tabular}{|c|c|c|c|}
\hline Components & $\begin{array}{c}\text { From Agricultural } \\
\text { Animal waste }\end{array}$ & $\begin{array}{c}\text { From waste } \\
\text { water }\end{array}$ & $\begin{array}{c}\text { Biogas } \\
\text { from landfill }\end{array}$ \\
\hline $\begin{array}{c}\text { methane }\left(\mathrm{CH}_{4}\right) \\
\text { carbon-dioxide } \\
\left(\mathrm{CO}_{2}\right)\end{array}$ & $60-70 \%$ & $55-60 \%$ & $45-55 \%$ \\
\hline nitrogen $\left(\mathrm{N}_{2}\right)$ & $30-40 \%$ & $35-45 \%$ & $30-40 \%$ \\
\hline $\begin{array}{c}\text { hydrogen-sulphide } \\
\left(\mathrm{H}_{2} \mathrm{~S}\right)\end{array}$ & $<1 \%$ & $<1 \%$ & $5-15 \%$ \\
\hline $\begin{array}{c}\text { ammonia }\left(\mathrm{NH}_{3}\right) \\
\text { siloxanes }(\mathrm{SiOx})\end{array}$ & $<600 \mathrm{mg} / \mathrm{m}^{3}$ & $<600 \mathrm{mg} / \mathrm{m}^{3}$ & $<100 \mathrm{mg} / \mathrm{m}^{3}$ \\
\hline oxygen $\left(\mathrm{O}_{2}\right)$ & $0-50 \mathrm{mg} / \mathrm{m}^{3}$ & $0-50 \mathrm{mg} / \mathrm{m}^{3}$ & $0-50 \mathrm{mg} / \mathrm{m}^{3}$ \\
\hline
\end{tabular}




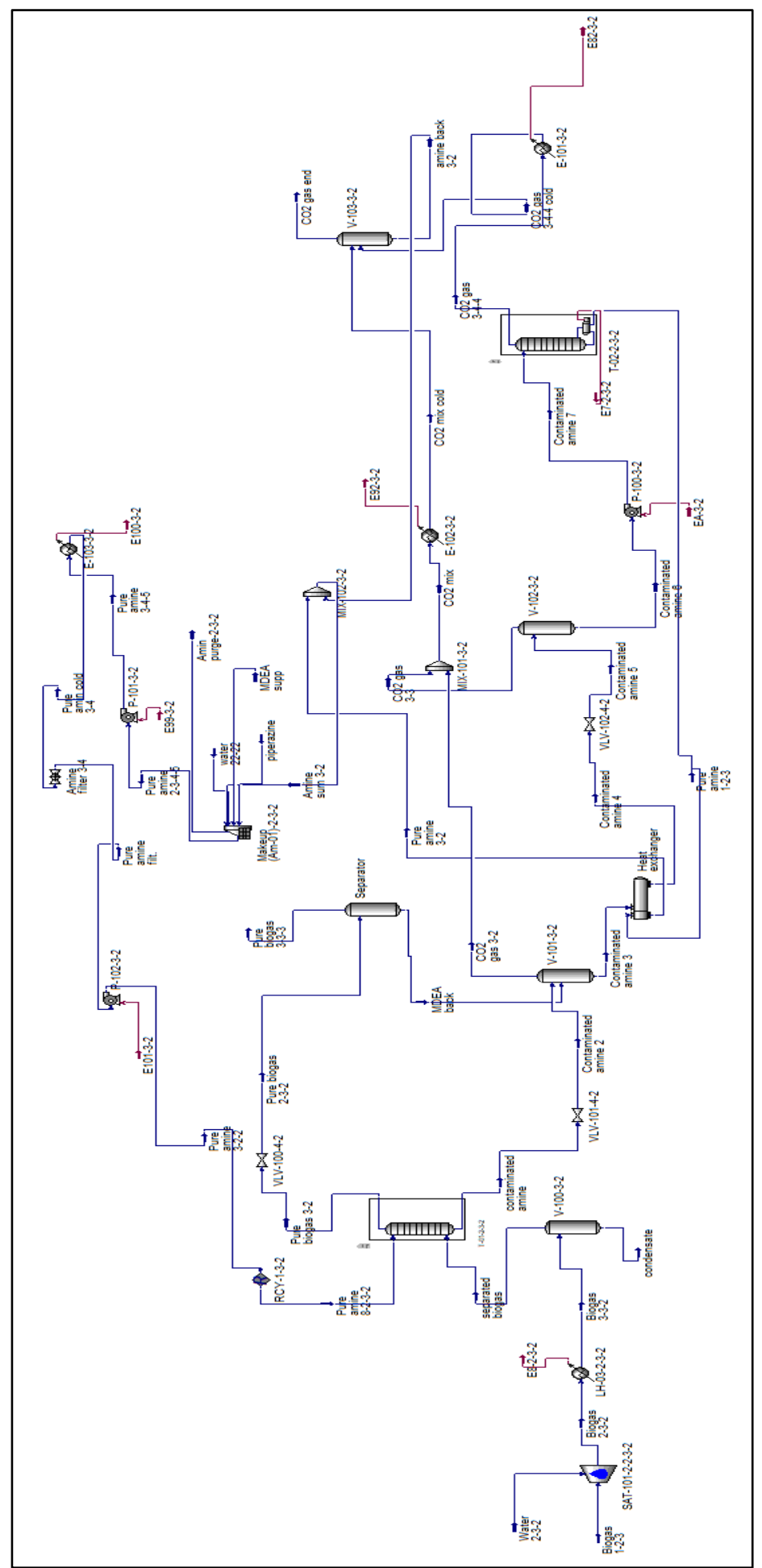

Figure 3. Hysys model. 
Figure 3 shows the model created in the software. In the first step, we saturated the biogas with the help of a saturator so that the water content corresponded to the real raw gas. It then passed through a condensate separation unit where the unwanted liquid particles were separated, and then this treated biogas flows into the absorber where the washing process took place. Meanwhile, the contaminated amine left at the bottom of the absorber and then flowed into the regeneration tower through two separators and a heat exchanger unit. The separator units perform the $\mathrm{CO}_{2}$ capture, and then in a postseparator the amounts of $\mathrm{CO}_{2}$ separated in the given steps are combined. From the regeneration unit, the already purified amine was returned to the absorber. However, since regeneration occurs at relatively high temperatures with boiling, the system may be deficient in components. For this reason, the purified amine is placed in a so-called "make-up" unit, where MDEA, or MEA (it depends on which amine is used in the model) -and water can be replaced each time. Finally, a "recycle" (R) unit has been incorporated that maintains the cyclical nature of the process.

\section{Results}

After the model was completed, in the case of MDEA, we ran with three types of biogas compositions, which yielded the following results:

Table 2. Biogas compositions used for simulation (1), (2), (3) /MDEA/ (Source: own edit).

\begin{tabular}{|c|c|c|c|}
\hline Components & Composition (1) & Composition (2) & Composition (3) \\
\hline methane $\left(\mathrm{CH}_{4}\right)$ & $0,6115(61 \%)$ & $0,7341(73 \%)$ & $0,7500(75 \%)$ \\
\hline other comp. & 0,0057 & 0,0004 & 0,0005 \\
\hline nitrogen $\left(\mathrm{N}_{2}\right)$ & 0,0346 & 0,0196 & 0,0196 \\
\hline $\begin{array}{c}\text { carbon-dioxide } \\
\left(\mathrm{CO}_{2}\right)\end{array}$ & $0,3465(35 \%)$ & $0,2447(24 \%)$ & $0,2288(23 \%)$ \\
\hline oxygen $\left(\mathrm{O}_{2}\right)$ & 0,0006 & 0,0005 & 0,0005 \\
\hline hydrogén $\left(\mathrm{H}_{2}\right)$ & 0,0006 & 0,0005 & 0,0005 \\
\hline $\begin{array}{c}\text { hydrogen- } \\
\text { sulphide }\left(\mathrm{H}_{2} \mathrm{~S}\right)\end{array}$ & 0,0002 & 0,0001 & 0,0002 \\
\hline
\end{tabular}

In the first case, the biogas fed had relatively low methane content and a high $\mathrm{CO}_{2}$ content. After running the calculation procedures, the following result was obtained: with this procedure, the methane content can be increased to $68 \%$ and the carbon dioxide content can be reduced to $26 \%$. In the second case, the model calculated a methane content of $73 \%$ and a carbon dioxide content of $24 \%$. As a result, the methane content of biogas was increased to $81 \%$ and the $\mathrm{CO}_{2}$ content was reduced to $15 \%$. In the third case, a methane content of $83 \%$ and a $\mathrm{CO}_{2}$ content of $14 \%$ can be achieved. Overall, it can be concluded that although the model is functional, this amine solution (MDEA) does not achieve the purity $(90 \%<)$ required for biogas to be used as a motor propellant fuel. 
In the case of MEA, we ran the model with two types of biogas compositions, which yielded the following results:

Table 3. Biogas compositions used for simulation (1), (2), (3) /MEA/ (Source: own edit).

\begin{tabular}{|c|c|c|}
\hline Components & Composition (1) & Composition (2) \\
\hline methane $\left(\mathrm{CH}_{4}\right)$ & $0,6200(62 \%)$ & $0,7500(75 \%)$ \\
\hline other comp. & 0,0166 & 0,0073 \\
\hline nitrogen $\left(\mathrm{N}_{2}\right)$ & 0,0202 & 0,0195 \\
\hline $\begin{array}{c}\text { carbon-dioxide } \\
\left(\mathrm{CO}_{2}\right)\end{array}$ & $0,3400(34 \%)$ & $0,2200(22 \%)$ \\
\hline oxygen $\left(\mathrm{O}_{2}\right)$ & 0,0005 & 0,0005 \\
\hline hydrogén $\left(\mathrm{H}_{2}\right)$ & 0,0005 & 0,0005 \\
\hline $\begin{array}{c}\text { hydrogen-sulphide } \\
\left(\mathrm{H}_{2} \mathrm{~S}\right)\end{array}$ & 0,0022 & 0,0022 \\
\hline
\end{tabular}

In the first case, the biogas fed had relatively low methane content and a high $\mathrm{CO}_{2}$ content. After running the calculation procedures, the following result was obtained: with this procedure, the methane content can be increased to $73 \%$ and the carbon dioxide content can be reduced to $21 \%$. In the second case, the model calculated a starting methane content of $75 \%$ and a carbon dioxide content of $22 \%$. As a result, the methane content of biogas was increased to $87 \%$ and the $\mathrm{CO}_{2}$ content was reduced to $8 \%$. Overall, it can be concluded that a much higher methane content can be achieved by using MEA, which is still not enough $(90 \%<)$ to use biogas as a motor propellant. Therefore, further studies are needed.

\section{Conclusion}

In the course of the research, based on various literature, biogas-based technology was examined as a possible alternative to the use of fossil fuels. Nowadays, biogas is successfully used in several fields as an energy source, however, one of the most promising areas has been highlighted in this article as its use as a fuel. The use as a propellant requires the purification of biogas in order to ensure the highest possible methane content. The studies focused on amino purification technology. In the course of the research, we created a simulation model that realistically presents the operation of the process and, if the appropriate input parameters are entered, determines the output data that are important to us. Based on the calculation results, it can be said that the model is workable, based on the literature, we obtained real output parameters. However, the methane content of the purified biogas in the case of MDEA did not reach $90 \%$ in any of the compositions, so it cannot be used as a motor fuel. In the case of MEA it can be concluded that a much higher methane content can be achieved (87\%), but it is still not enough $(90 \%<)$ to use biogas as a motor fuel propellant. Further research is needed on this topic, taking into account the different amine concentrations, energy and economic issues. However, in our opinion these models can provide support for the construction, maintenance, or development of biogas plant treatment units. 


\section{Acknowledgments}

"The described article/presentation/study was carried out as part of the EFOP-3.6.1-16-2016-00011 "Younger and Renewing University - Innovative Knowledge City - institutional development of the University of Miskolc aiming at intelligent specialisation" project implemented in the framework of the Szechenyi 2020 program. The realization of this project is supported by the European Union, cofinanced by the European Social Fund."

\section{Sources}

[1] Tóth, T. Biogáz buszok elterjedésének hatása a megújuló tüzelőanyag-felhasználásra, TDK dolgozat. Budapesti Müszaki és Gazdaságtudományi Egyetem. 2013. Elérhető: https://tdk.bme.hu/KSK/DownloadPaper/Biogaz-buszok-elterjedesenek-hatasa-a-megujulo Letöltve: 2021.01.02.

[2] Szolyák, Zs. A biogázok felhasználása a városi közlekedésben - Hatékony Tisztítási technológiák, Müszaki Földtudományi Közlemények, 88. kötet, 2. szám (2019), pp. 52-61.

[3] Tihanyi, L., Szunyog, I., Szolyák, Zs. A motorhajtó energiahordozók felhasználási trendjei néhány EU tagországban, Magyar Energetika, XXV. évfolyam, 4. szám, 2018. augusztus

[4] Gasunie, N. Physical properties of natural gases. roningen : N.V. Nederlandse Gasunie, 1988.

[5] Bai, A. Biogáz előállításának technológiája. Elérhető: https://regi.tankonyvtar.hu/hu/tartalom/tamop412A/2011-

0085_biogaz_eloallitasanak_technologiaja/ch01.html Letöltve: 2021.02.03.

[6] Persson, M., Jönsson, O., Wellinger, A. Biogas upgrading to vehicle fuel standards and grid injection; IEA Bioenergy, December 2006. (http://www.biogasmax.eu)

[7] Kidnay, A. J., Parrish, W. R. „Fundamentals of Natural Gas Processing”, Ohio, Taylor and Francis Group, 2006.

[8] Process Simulation Using Aspen HYSYS V8 https://pdfcoffee.com/process-simulation-usingaspen-hysys-v80-eng-ahmed-deyab-fares-pdf-free.html Letöltve: 2021.01.02. 